\title{
Friedman Meets Hayek on Money and Prices in Canada
}

\author{
KAM HON CHU \\ Memorial University of Newfoundland *
}

\begin{abstract}
Though both classical liberals, Friedman adopted the quantity theory of money and used the general price indexes and aggregate data in empirical analysis, whereas Hayek rejected aggregative analyses as potentially misleading and focused on the impact of money on relative prices in his business cycle theory. This study shows theoretically that when the central bank minimizes the monetary shock to maintain stability in the general price level, it also maintains simultaneously relative price stability, thus narrowing the divergence between Friedman and Hayek. This finding is empirically verified by Canada's experience with inflation targeting since 1991.
\end{abstract}

JEL Classifications: B31, E31, E58

Keywords: Milton Friedman, F.A. von Hayek, Inflation Targeting, Price Level Targeting, Relative Price Variability

\section{Introduction}

It is almost indisputable that Milton Friedman and Friedrich von Hayek are the two most famous champions of classical liberalism and free-market economics in the $20^{\text {th }}$ century. Although these two great thinkers shared common tenets of classical liberalism, there are differences and divergences in their economics, particularly in the areas of money and the business cycle. While both shared a common ground of being anti-Keynesian in the area of monetary economics and macroeconomics, their views and methods are quite different from each other, as Hayek described "Milton and I agree on almost everything except monetary policy" (Hayek 1994, p.144) without giving further elaborations on their disagreement. So what are their major differences in monetary theory and policy? Why did they differ? Furthermore, can their differences in one way or another be reconciled, or at least the gap be narrowed to some extent? These are some of the questions that motivate this paper.

\footnotetext{
* I am very grateful to the editor, two anonymous referees, Professors David Laidler, Angelo Melino and John Smithin for their suggestions and comments on earlier versions of this paper. All remaining errors are, however, my sole responsibility.

(C) 2016 Kwan Hon Chu. Licensed under the Creative Commons Attribution - Noncommercial 3.0 Licence (http://creativecommons.org/licenses/by-nc/3.0/. Available at http: //rofea.org.
} 
It goes without saying that it is an intimidating, if not impossible, task to compare these two giants' economic thoughts, given the depth and breadth of their works. This remains the case even if we compare only their works in monetary economics. To limit the scope and to make this paper manageable, we focus on their views on neutrality of money and the related methods of monetary analysis and policy prescriptions, particularly regarding price stability, that follow from their different views and concepts of monetary neutrality.

In a nutshell, although both Friedman and Hayek agreed upon the short-run non-neutrality of money, their views on the long-run neutrality of money somewhat differ because of Friedman's method of aggregative analysis. In Friedman's quantity-theoretic framework, the neutrality of money is the proposition that a change in the quantity of money results in a proportionate change in the absolute general price level, leaving all real variables, like real interest rate, real output, etc., as well as relative prices intact. By contrast, Hayek rejected such aggregative analyses as potentially misleading and instead focused on the impact of money on relative prices in his business cycle theory. More details of their views will be expounded in Section 2 below.

This paper demonstrates that the above-mentioned main difference between Friedman and Hayek can to some extent be reconciled. Based on the definition of a consumer price index and assuming that the price of a good is subject to both real and monetary shocks, this paper derives theoretical results indicating that a monetary policy or rule that minimizes the variance in the general price level due to monetary shocks will also minimize the variances in relative prices at the same time. This is analogous to the "divine coincidence," i.e., stabilizing inflation is equivalent to stabilizing the output gap (Blanchard and Gali 2007).

Empirically, the above theoretical finding is tested with reference to Canada's experience with inflation targeting since 1991. Casual empiricism tends to suggest that Canada has achieved a high degree of monetary and price stability since the Bank of Canada adopted a monetary rule to target inflation in February 1991. Based on monthly data from the CANSIM database, we formally test this observation by comparing the variances of the consumer price index and the various monetary aggregates during the inflation targeting regime (from February 1991 to March 2014) with their counterparts in the previous regime (from June 1970 to January 1991). More importantly, we also test our theoretical finding whether the variances in relative prices have also been stabilized at the same time by examining the variances of 146 relative prices as well as the relative price between consumption goods and capital goods across the two regimes. As can be seen in detail in Section 4 below, the empirical results confirm a higher degree of stability in both the general price level and relative prices under inflation targeting.

Admittedly, this study will at best be a small contribution to the voluminous literature related to the works of Friedman and Hayek. Nonetheless, this study is also relevant to a couple of strands of literature. First, it is related to a huge, traditional literature in price-level 


\section{KAM HON CHU Friedman Meets Hayek on Money and Prices}

targeting, which, since the seminal work of Svensson (1999) has been drawing more and more attention of the economics profession, particularly in recent years (see, e.g. Murchison 2010, Melino 2012, Kamenik et al 2013, among many others; and the survey by Ambler 2009). Our finding suggests that one potential advantage of price-level targeting is the associated lower variability in relative prices.

Second, this study can also be relevant to another sizable empirical literature that explores the relationship between inflation and relative price variability initiated in the 1970s by Lucas (1973), Vining and Elwertowski (1976) and Parks (1978), to name just a few, and continues to proliferate in recent years (e.g., Choi 2010, Choi, Kim and O'Sullivan 2011, among many others). There are, however, subtle differences between those studies and this study. In this study, the focus is on the relationship between variance of the general price level and the variances of relative prices, whereas the abovementioned empirical literature largely explores the relationship between inflation rates of various goods and aggregate inflation (or, more accurately, changes in the individual component indexes relative to changes in the general price index). However, the central message in either case appears to be essentially similar: instability of the general price level is associated with higher relative price variability.

The organization of this paper is straightforward. The next section offers a brief account of Hayek's and Friedman's views on money and prices. Section 3 and the Mathematical Appendix provide the theoretical findings and derivations. The descriptions of the data, the hypothesis tested and the empirical methods and results can be found in the penultimate section and the data appendix, followed by the conclusion.

\section{Hayek's and Friedman's Views on Money and Prices}

It may not be surprising at all that Friedman and Hayek had different views in monetary theory and policy given that Friedman is one of the leaders of the post-war Chicago School of Economics and monetarism, ${ }^{1}$ whereas Hayek was regarded as among the fourth generation of the Austrian School of Economics (see e.g. Skousen 2005 and Garrison 2013). In the area of money, Friedman is quite well known among the economics profession for his criticisms of Keynesianism and his Monetarist Counter-revolution. Probably lesser known among economists, especially the younger generations, is that Hayek was one of the chief contemporary critics of Keynes's work on money (Hayek 1931, 1932).

This paper is by no means the first attempt in the literature to compare the monetary economics of Friedman and Hayek (see, for example, Bellante and Garrison 1988, Garrison 2013). As will be seen very shortly below, this paper differentiates from the other studies by

1 Friedman himself did not like the label "monetarism," which was coined by Brunner (1968). Here we use the term for the sake of convenience in exposition, taking it to represent Friedman's views and positions as contrast to the Hayekian views without any derogatory connotation. 
focusing on the roles of the general price level and relative prices in their monetary analyses. As already mentioned in the introduction, Friedman adopted the quantity theory of money as his theoretical framework and used the general price indexes and aggregate data in empirical analysis, whereas, by contrast, Hayek rejected such aggregative analyses as potentially misleading. Instead, he focused on the impact of money on relative prices in his business cycle theory. In the paragraphs to follow in this section, we will first describe their different notions of neutrality of money. It follows naturally that their monetary policy descriptions also differ because of their divergent concepts of monetary neutrality and differences in research methodology. Then in Section 3 we will show theoretically how this main difference between them can to some extent be reconciled. More specifically, assuming that the price of a good is subject to both real and monetary shocks and also that the central bank follows a rule-based monetary policy that minimizes the monetary shock, we can derive results indicating that a monetary policy or rule that minimizes the variance in the general price level due to the monetary shock will also minimize the variances in relative prices at the same time.

\subsection{The Hayekian Views}

One important concept in Hayek's monetary analysis is the notion of monetary neutrality. Hayek did not invent the concept or the term "neutral money" himself, although he gave currency to the expression in his early writings (e.g. Hayek 1933, 1935). As a matter of fact, he adopted the concept from his contemporaries and predecessors like J.G. Koopmans, and Wicksell. It is a concept designed as an instrument for theoretical analysis. According to Hayek (1935, p. 130), neutrality of money "refers to the set of conditions, under which it would be conceivable that events in a monetary economy could take place ... as if they were influenced by the 'real' factors which are taken into account in equilibrium economics." Simply put, money is present to facilitate indirect exchange in a money-using economy and it is neutral when the economic process is influenced by real factors only according to the equilibrium theory under the assumption of barter. ${ }^{2}$

In Hayek's theory of business cycle, money, however, does not remain neutral when "artificial" money or credit creation induces a divergence between the market interest rate and the natural rate of interest through forced saving. ${ }^{3}$ Initially the interest rate effect due to a

\footnotetext{
${ }^{2}$ Hayek did not explicitly spell out what he exactly meant by the equilibrium theory in his exposition of the neutrality of money. However, if we put his writings as well as the development of economic science into perspective, we can conjecture that what he had in mind about monetary neutrality was probably that an economic equilibrium is first determined by real factors and relative prices in a way similar to a Walrasian general equilibrium system and then money is introduced into the system to facilitate exchange without influencing relative prices.

${ }^{3}$ In an economy under full employment of resources, when firms use the newly created purchasing power from credit to bid resources away from consumers, consumers are forced to consume
} 


\section{KAM HON CHU Friedman Meets Hayek on Money and Prices}

lower market interest rate raises the profitability of all investments because of cheaper loans, but with greater increases in profitability in more roundabout production processes (i.e. capital deepening). ${ }^{4}$ This leads to a diversion of labour from the production of final (consumption) goods into the production of intermediate (capital) goods, and consequently a relative price effect causes increases in the prices of consumption goods relative to those of capital goods. ${ }^{5}$ Based on the Ricardo effect, as Hayek $(1942,1967)$ argued, the higher prices of consumption goods reduce real wages, which in turn induce new investment in less roundabout production methods (capital shallowing). The monetary or credit expansion thus triggers an investment boom initially, but it will ultimately lead to a slump as there are constraints on real resources and savings. For the resources initially diverted into the more roundabout processes are subsequently locked into partially completed projects and cannot be reallocated to meet demand for consumption goods.

It is not the right place here to discuss the merits and shortcomings of the Hayekian theory of business cycle in detail. ${ }^{6}$ For the purpose of this paper, the theory can perhaps be recapitulated as follows: in a Hayekian world, undue monetary expansion beyond voluntary savings disturbs the structures of capital and relative prices, which leads to mal-investment, mis-allocation of resources and ultimately economic fluctuations because the price system communicates false information about consumer preferences and resource availability. More importantly, Hayek rejected any direct causal relationship between the total quantity of money, the general level of prices and the total amount of output because "none of these magnitudes as such ever exerts an influence on the decisions of individuals; yet it is on the assumption of a knowledge of the decisions of individuals that the main propositions of nonmonetary economic theory are based. Simply put, there is no causal connection between

involuntarily less than they desire. This phenomenon is known as forced saving in Hayek's business cycle theory.

${ }^{4}$ Despite the term "roundabout production" is rarely used in the modern literature and may be perceived as antiquated language, I still use it here for at least two reasons. First, it is the terminology and concept originally used by Hayek and his Austrian predecessors, notably Bohm-Bawerk. Second, and more importantly, it is implicitly related to a time dimension (period of production) and also to some other subtle conceptual issues such that it is not exactly identical to, and hence can be replaced by, later related concepts like capital intensity. See, for example, Hicks (1973) for a more detailed exposition.

${ }^{5}$ This macroeconomic theorizing in terms of consumption goods and capital goods is rather common in the pre-WW II literature. See for example Keynes (1930) and Robertson (1926). Laidler (2003) gives an excellent exposition of the interwar debate on the relationships among the price level, relative prices and the business cycle.

${ }^{6}$ The reader who is interested in Hayek's theory of business cycle may find, in addition to Hayek's original works, the collected studies by other researchers in Colona and Hagemann (1994) highly relevant and useful. 
macro totals and micro decisions. It is to this 'individualistic' method that we owe whatever understanding of economic phenomena we possess; that the modern 'subjective' theory has advanced beyond the classical school in its consistent use is probably its main advantage over their teaching. If therefore, monetary theory still attempts to establish causal relations between aggregates or general averages, this means that monetary theory lags behind the development of economics in general." (1935, p.4) In brief, the impact of money on economic activity is microeconomic in nature, working through induced changes in relative prices and therefore the general price level has little relevance to economic stability. In particular, stability of the general price level cannot be automatically regarded as a sign of monetary stability because misallocation of resources due to credit expansion can occur despite price level stability. Hayek (1925) had pointed out this possibility of the fallacy of the usefulness of statistical averages, such as a general price index, with reference to the US experience in the 1920s. According to his analysis, changes in the major business indicators remained so stable in the early 1920s that they gave a misleading picture of stability, which together with the Federal Reserve's passive discount policy based on the Banking School's real bills doctrine failed to achieve its goal of stabilizing business cycles, as the undue credit expansion would set the course for the economy towards a subsequent financial crisis. ${ }^{7}$

In this aspect, Hayek differed from the quantity theorists such as Irving Fisher in his applying the Cantillon effect to prices, which asserts that changes in the general price level caused by monetary expansion vary with the nature of the expansion and also that the change in the general price level is almost always associated with changes in relative prices. This implies the denial of the homogeneity postulate and leads to the conclusion that money is not neutral. Hayek rejected the crude quantity theory that focuses exclusively on the relationship between the quantity of money and the general price level. All these contrast sharply with Friedman's famous helicopter money model (Friedman 1969). Following his Austrian methodology, Hayek objected to the use of aggregates or statistical averages because such use is incompatible with methodological individualism, hides the real action in the economy, and is literally meaningless. In the early 1920s Hayek attended Mitchell's lectures when he visited the United States and also he had reviewed Wesley Mitchell's and Irving Fisher's proposals for the usefulness of index numbers. However, he was not convinced by their methods and had reservations about the use of averages and aggregates in economic theory because of the potentially misleading conclusions that might be drawn about individual behaviour based on statistical aggregates or averages. He likened the positivist-empiricist approach to the German Historical School and was sceptical whether the study of historical

\footnotetext{
${ }^{7}$ At the time of writing his review of the US monetary policy, of course, Hayek did not have perfect foresight about the outbreak of the Great Depression in 1929. However, he raised warning flags for the lack of reliable leading indicators and a coherent theoretical foundation in the Federal Reserve's credit policy.
} 


\section{KAM HON CHU Friedman Meets Hayek on Money and Prices}

development or statistical methods could arrive at the laws underpinning economic phenomena and hence make future individual behaviour predictable. In his view, theory rather than statistics should play the leading role in the investigation of economic phenomena. We have already seen above how the Federal Reserve's failure in stabilizing the business cycle based on statistical indicators. As a further example, Hayek questioned whether, when there was a change in the production costs of a commodity, Fisher's proposal of a compensated dollar based on the use of a general price index would achieve stabilization or just postpone the inevitable balancing of demand and supply required to restore equilirium, not to mention whether such artificial stabilization was an ideal state of affairs policymakers should aim at or not.

\subsection{Friedman’s Monetarism}

In contrast, the influences of Fisher and Mitchell can be found in Friedman's theoretical and empirical works. It would not be a surprise to find Mitchell's profound influence on Friedman because Mitchell was Friedman's teacher at Columbia University, colleague at the National Bureau of Economic Research and also friend (Friedman and Friedman 1998). The classic of Friedman and Schwartz (1963) followed closely the spirit and methodology of the National Bureau of Economic Research founded by Mitchell and used aggregate data and statistical techniques to demonstrate that money growth was the driving force behind the business cycle of the Great Depression. Based on the observed asymmetrical boom-bust correlations in U.S. business cycle, Friedman (1964[1969], 1993) later put forward a "plucking model" of business cycle fluctuations, according to which real output is plucked below trend as a result of money supply contraction. Furthermore, he also argued that the empirical evidence - a zero correlation between the amplitude of a boom and that of the succeeding bust but a high correlation between the size of a boom and that of the preceding bust - was decisive refutation of the Austrian theory of the business cycle. ${ }^{8}$ However, Garrison (1996) counter-argued that the empirical findings are broadly consistent with both Monetarists and Austrian views for they are working at different levels of aggregation. The Austrian theory works at a lower level of aggregation: during a credit-induced boom, resources are reallocated from the consumption-goods sector to the investment-goods sector and hence there are differential movements in the different stages of production from investment to consumption. Such relative movements in the outputs of the two sectors and malinvestment through forced saving are something going on within the output aggregate and

\footnotetext{
${ }^{8}$ Friedman's claim can be found in his interview with Hammond (1992). Friedman inferred, rightly or wrongly, that this striking asymmetry in the empirical findings is inconsistent with the Austrian business cycle theory which sees the excesses of the prior expansion the source of a deep depression, or statistically speaking the size of a boom should be highly correlated with that of the succeeding bust.
} 
hence they may not be conspicuously reflected when a single output aggregate is used in empirical analysis. Similarly, Bellante and Garrison (1988) argue that the two theories are complementary aspects of the business cycle. In a sense this study shares with these authors that the differences in Friedman's and Hayek's theories can to some extent be reconciled by looking at the different levels of aggregation (i.e., the general price level vs. relative prices).

From Friedman and Schwartz (1963) and Friedman's plucking model, it can be seen that the thrust of Friedman's argument is similar to Hayek's theory in that monetary factors cause the business cycle, but it contrasts sharply Hayek's in the reliance on aggregative analysis and the use of statistical techniques. Such analytical approach and methods are common in Friedman's other studies, such as Friedman (1959), Friedman and Meiselman (1963), to name just a few. Hayek undoubtedly objected to this aggregative and econometric approach to macroeconomic analysis which became dominant after WWII.

Similarly, Fisher had both direct and indirect influences on Friedman's monetary theory and empirical analysis (see Bordo and Rockoff 2013 for more detailed discussion). Theoretically, Friedman's seminal paper (1956) recasts a Keynesian-type aggregate money demand function -- with the general price level as one of the determinants -- to derive results and conclusions that can be traced back not only to the Chicago "oral tradition" but also to Fisher (1922) and earlier quantity theorists (see e.g. Laidler 1991). Like Fisher, Friedman used aggregates and the general price level in his theoretical analysis and concluded that substantial changes in prices or nominal income are almost invariably the result of changes in the nominal supply of money. In the long run, increases in the money supply in excess of growth in real output are followed by proportionate increases in the general price level (Friedman 1956, 1970, 1971). As already mentioned in the introduction, although both Friedman and Hayek agreed upon the short-run non-neutrality of money, their views on the long-run neutrality of money somewhat differ because of Friedman's method of aggregative analysis. In Friedman's case, the neutrality of money is the proposition that a change in the quantity of money results in a proportionate change in the absolute general price level, leaving all real variables, like real interest rate, real output, etc., as well as relative prices intact.

The above brief exposition about Hayek's and Friedman's views on money and prices is by no means exhaustive. Nonetheless, it at least highlights some major differences between them, particularly the roles of relative prices and the absolute price level. An interesting theoretical question thus follows: Who was right, Friedman or Hayek? This question has not only importance for monetary theory but also relevance to the practice of monetary policy. For if Hayek was right, then the absolute price level would be irrelevant; and many central banks' current practice of inflation targeting with reference to the general price level, whether measured by the CPI or GDP deflator, would be misguided. But if Friedman was right, then relative prices would more or less take care of themselves and remain unaffected so long as 


\section{KAM HON CHU Friedman Meets Hayek on Money and Prices}

money was neutral; and the central bank could thus rely on the general price level as an indicator to guide its policy without having to spend huge resources on keeping track of the large number of relative prices. Of course, the possibility that their views are not mutually exclusive should not be entirely ruled out as well. If this is the case, then a further question is: under what condition or conditions can their two views be reconciled and compatible with each other? These questions will be addressed in detail in the Section 3.

\subsection{A Comparison of Friedman's and Hayek's Views}

Before we proceed to the theoretical and empirical analysis, perhaps it is desirable to facilitating the reader, especially the modern reader who may not be familiar with issues that belong to the history of economic thought, by recapitulating our expositions above as well as outlining the main differences between Friedman's and Hayek's views on money and prices. No attempt is made to go into detailed discussion of the issues here, simply because of space limitation and also each issue can potentially be a research topic in its own right. Nonetheless, we will return to some of these issues in more detail in our theoretical analysis below whenever appropriate.

As far as monetary economics is concerned, the main similarities and differences between Friedman and Hayek can perhaps be summarized as follows:

1). Both Friedman and Hayek can be grouped under the Ricardian metallic money tradition or the Currency School according to Hicks's contentious schema (Hicks 1967), but Hayek's intellectual heritage also includes Henry Thornton, who belongs to the credit money tradition and can be regarded as the precursor of the Banking School.

2). It follows that both Friedman and Hayek can be regarded as quantity theorists as far as the effects of money on real output and prices are concerned and they shared a common view - money is non-neutral in the short run but neutral in the long run.

3). However, their concepts of neutrality of money differ. In Friedman's case, money is neutral when changes in money result in proportionate changes in the absolute general price level with all real variables intact, whereas in the case of Hayek money is neutral if its changes do not affect relative prices.

4). Partly due to the different concepts of neutrality, Friedman employed aggregate data and statistical methods in his analysis, whereas Hayek was sceptical of such aggregative analysis and the application of the "crude" quantity theory of money.

5). It follows from their different concepts of neutrality and analytical methods that Friedman paid more attention to the harmful effects of inflation and deflation, whereas Hayek emphasized the mis-allocation of resources due to distorted relative prices. 
Review of Economic Analysis 8 (2016) 69-96

6). To tackle those harmful effects, Friedman advocated monetary management with the central bank controlling the quantity of money in circulation (e.g. M2 in his case). By contrast, Hayek doubted whether there was such thing as the quantity of money because of substitutability among assets and economic agents altered liquidity preferences. Instead, he was more concerned about the destabilizing effects of credit expansion (following monetary injections) in an intertemporal framework.

7). Nevertheless, both Friedman and Hayek favoured a rule-based monetary policy. Friedman favoured a k\% money supply growth rule, preferably stipulated by a monetary constitution. Hayek preferred the gold standard as it automatically constrained and corrected excessive monetary expansion through the Humean price-specie-flow mechanism.

8) In terms of international monetary arrangements, Friedman was a pioneer in advocating flexible exchange rates, whereas Hayek favoured fixed exchange rates under the gold standard.

9). However, recognizing the political infeasibility to return to the gold standard, the persistent abuse of the government prerogative in money, and that only the market could discover the optimal quantity of money, Hayek proposed denationalization of money later in his life. Although not a proponent of free banking, Friedman was a persistent critic of central banking.

The above list is by no means exhaustive. We will also return to some of these issues later in this paper, particularly the neutrality concepts regarding changes in the general price level versus changes in relative prices in the theoretical analysis and empirical study to follow,

\section{Are Friedman's and Hayek's Views on Money and Prices Incompatible?}

Based on a simple formula of a general price index and some basic statistical operations, we examine in this section (i) the relationship between changes in relative prices and changes in the general price level, and (ii) the condition or conditions under which Hayek's and Friedman's views discussed above can become compatible with each other.

To begin with, consider the absolute or general price level as represented by the Consumer Price Index (CPI). As a Laspreyer index or base-weighted price index, the formula for CPI for period $t$ is given as:

$$
C P I_{t}=P_{t}=\frac{\sum_{i} P_{i t} Q_{i 0}}{\sum_{i} P_{i 0} Q_{i 0}}
$$




\section{KAM HON CHU Friedman Meets Hayek on Money and Prices}

where $P_{t}$ stands for the general price level, $Q_{i o}$ is the quantity of the $i$ th good in the base year, $P_{i t}$ is the price of the $i$ th good at time $t$, whereas $P_{i o}$ is its price in the base year, and $i=1,2,3$, $\ldots \mathrm{n}$, where $\mathrm{n}$ is the total number of goods and services included in computation of the CPI.

The above formula can be alternatively expressed as:

$$
P_{t}=\sum_{i} w_{i} P_{i t}
$$

where $w_{i}$ is the ratio of $Q_{i o}$ to the denominator in Equation (1) above (i.e., the total expenditure on the basket of goods and services in the base year), and it can be interpreted as the weight of good $i$ in the CPI basket. The weight $w_{i}$ is a constant as long as the CPI is not reconstructed or re-based. Needless to say, $P_{i t}$ is not a constant. As a first approximation, suppose $P_{i t}$ is specified as follows:

$$
P_{i t}=P_{i 0}+q_{i t}+a_{i m}
$$

where $q_{i t}$ is a random variable representing a real shock due to a change in the demand for good $i, m_{t}$ is another random variable representing the monetary shock due to the central bank's monetary policy, and $a_{i}$ (where $a_{i} \neq a_{j}$ in general for $i \neq j$ ) is the response of $P_{i t}$ to the monetary shock to represent Hayek's idea that a monetary injection induces differential price effects on the various types of goods in the economy. Given the above specification, it follows that the mean and variance of $P_{i t}$ are respectively:

$$
E\left(P_{i t}\right) \equiv \mu_{i}=P_{i 0}+\mu_{q i}+a_{i} \mu_{m}
$$

and

$$
V\left(P_{i t}\right) \equiv \sigma_{i}^{2}=\sigma_{q i}^{2}+a_{i}^{2} \sigma_{m}^{2}
$$

where $\mu$ qi and $\sigma q i 2$ are respectively the mean and variance of the real shock, i.e., random variable qit, and $\mu \mathrm{m}$ and $\sigma \mathrm{m} 2$ are respectively the mean and variance of the monetary shock, i.e., random variable mt.9 If it is assumed that the real and monetary shocks are uncorrelated, then the covariance between Pit and Pjt, is:

$$
\operatorname{COV}\left(P_{i t}, P_{j t}\right)=\sigma_{i j}+a_{i} a_{j} \sigma_{m}^{2}
$$

\footnotetext{
${ }^{9}$ It can be assumed that the shocks have zero means, i.e., $\mu_{q i}=\mu_{m}=0$. However, this assumption is nonessential and does not affect our results.
} 
where $\sigma_{i j}$ is the covariance between the real shocks to $\operatorname{good} i$ and $\operatorname{good} j .{ }^{10}$

With the above results and assumptions, we can derive the mean and variance of the general price level respectively as follows:

$$
E\left(P_{t}\right)=\sum_{i} w_{i}\left(P_{i 0}+\mu_{q i}+a_{i} \mu_{m}\right)
$$

and

$$
V\left(P_{t}\right)=\sum_{i} w_{i}^{2} \sigma_{q i}^{2}+\sum_{i} \sum_{j \neq i} 2 w_{i} w_{j} \sigma_{i j}+\left(\sum_{i} w_{i}^{2} a_{i}^{2}+\sum_{i} \sum_{j \neq i} 2 w_{i} w_{j} a_{i} a_{j}\right) \sigma_{m}^{2},
$$

Details of the derivation can be found in the Mathematical Appendix. In the above equation, the first and the second term on the left-hand side are respectively the weighted sum of the own variances and the weighted sum of covariances due to the real shocks, whereas the last term in parentheses contain the counterparts due to the monetary shock.

Next consider the relative prices. Let us take the price of the first good, $P_{1}$, as the numeraire. Then the price index can now be expressed as:

$$
P_{t}=w_{1}+\sum_{i=2} \frac{w_{i} P_{i t}}{P_{1 t}}
$$

It can be seen from the above equation that even if the central bank is able to keeps $P_{t}$ at a constant level, say, under price level targeting, it does not imply that the relative prices $P_{i t} / P_{l t}$, for $i=2,3,4, \ldots \mathrm{n}$, are also constant because there are infinite combinations of $P_{i t} / P_{l t}$ that can satisfy this equation. Though not trained as a mathematical economist, Hayek was absolutely right in his insight that price level stability cannot be automatically be regarded as a sign of monetary stability because relative prices can still be induced to change by a change in the money supply.

Now consider the variations in relative prices. For any arbitrary pair of prices $P_{i t}$ and $P_{j t}$, the variance of the relative price can be approximated as (see the Mathematical Appendix for the derivation):

$$
V\left(\frac{P_{i t}}{P_{j t}}\right)=\left(\frac{\mu_{i}}{\mu_{j}}\right)^{2}\left[\left(\frac{\sigma_{q i}^{2}}{\mu_{i}^{2}}+\frac{\sigma_{q j}^{2}}{\mu_{j}^{2}}-\frac{2 \sigma_{i j}}{\mu_{i} \mu_{j}}\right)+\left(\frac{a_{i}^{2}}{\mu_{i}^{2}}+\frac{a_{j}^{2}}{\mu_{j}^{2}}-\frac{2 a_{i} a_{j}}{\mu_{i} \mu_{j}}\right) \sigma_{m}^{2}\right]
$$

\footnotetext{
${ }^{10}$ The sign and magnitude of $\sigma_{i j}$ depend on respectively whether good $i$ and good $j$ are substitutes or complements and also the degree of substitutability or complementarity.
} 


\section{KAM HON CHU Friedman Meets Hayek on Money and Prices}

The interpretation of the above equation is similar to that of Equation (8) above. On the righthand side of the equation, the first term inside the brackets is the variations due to the real shocks, whereas the second term is due to the monetary shock. Based on Equations (8) and (10), it is obvious that a monetary shock or injection (as represented by $\sigma_{m}{ }^{2}$ ) would induce variability in both the general price level and relative prices and that in general the two variations are not the same. In this general case, Hayek is definitely correct. But it is also quite obvious that in the special case in which ${\sigma_{m}}^{2}=0$, variances in the general price level as well as in relative prices can be attributable to real shocks only. In general, all other things equal, the less volatile the monetary shock (i.e., a lower value of ${\sigma_{m}}^{2}$ ), the smaller the variance in the general price level and smaller in relative prices as well. This is similar to raising the signal-to-noise ratio in Lucas's model (1972) in which economic agents face a signal extraction problem because of imperfect information about shocks to the demands for individual goods and the monetary shock. Or put differently in non-technical terms, inflation distorts the proper role of relative prices in the optimal allocation of resources via the price system.

Contrary to what Hayek claimed, therefore, the general price level is not entirely irrelevant or meaningless from this perspective. For a central bank which chooses a monetary policy to maintain price level stability based on the CPI as a target or indicator, it is also at the same time minimizing the volatility in the induced changes in relative prices due to monetary injections. If the central bank's objective is to maintain monetary and price stability, then in this case it makes little, if any at all, difference whether the central bank takes heed to Hayek's or Friedman's view, although the former emphasized the important role of relative prices in the transmission mechanism whereas the latter, partly for practical and instrumental reasons, preferred the use of a general price level index in the theory and practice of monetary economics. In principle Hayek endorsed the monetarist objective that monetary policy should not be a cause of disturbances to real economic activity, although he was adamantly critical of Friedman's methods of analysis (see e.g. Friedman 1968, and Hayek 1978).

In this respect, the gap between Hayek and Friedman is to some extent narrowed. The above finding is also consistent with the fact that both Friedman and Hayek favoured a rulebased monetary policy, as $\sigma_{\mathrm{m}}{ }^{2}$ under a monetary rule would be smaller than under discretion. ${ }^{11}$ Yet they have different orientations. Friedman's monetary policy prescription is quite well-known to us. Following his teacher Henry Simons (1936), Friedman preferred rules over discretion or authorities in the conduct of monetary policy. Taking the money supply as exogenous and assuming a stable money demand function, he advocated a fixed

${ }^{11}$ Under the "ideal" case, for instance, in which the central bank implements a fully anticipated monetary rule and is able to keep the actual money supply always at the target level, both the mean and variance of the monetary shock would be zero. 
rule under which the central bank is constrained by a monetary constitution to allow the supply of fiat money to grow at a constant $\mathrm{k} \%$ per year, where $\mathrm{k}$ is determined to equal to the secular GDP growth rate after allowing for secular changes in the velocity of circulation (Friedman 1961, 1968). Theoretically, monetary shocks to the economy should be reduced under such a k-percent money growth rule because it avoids the potentially destabilizing effects arising from the long and variable lags of a discretionary monetary policy.

However, Hayek had reservations about adopting this simple $\mathrm{k} \%$ monetary rule partly because he doubts if the money supply can be well defined and precisely measured for this rule to be practicable. In contrast to Friedman who was an advocate of floating exchange rates (Friedman 1988), Hayek was initially a believer in the gold (bullion) standard as a rule that imposes a discipline upon monetary authorities to prevent them from abusing their monopoly power in supplying money. A commodity-money standard is a form of monetary rule that requires the monetary authority to manage the money stock in such a way that the money price of the specified commodity - gold in the case of the gold standard - be kept constant over time. Under the pure form of a gold standard, monetary shocks would be tied to fluctuations in the world's monetary gold reserves due to gold production and gold hoards rather than from the central bank's monetary policy.

But the restoration of the gold standard had become so politically and practically infeasible (Hayek 1939) that Hayek subsequently put forward a proposal for a commodity reserve currency (Hayek 1943) - also a rule-based monetary regime. According to this proposal, money would be backed by stored commodities in some fixed proportion and money could be redeemed in a fixed unit of those commodities or vice versa, depending on whether it would be profitable to do so. This scheme, as Hayek claimed, would not only impose an automatic limit on the supply of money but also act as a counter-cyclical mechanism for limiting the business cycle.

As can be seen from above, although Hayek had modified his views over time to adapt to the changing political and economic conditions, he remained in favour of a rule-based monetary policy or regime. In his later years, however, Hayek doubted if the monetary authorities would actually follow any rules in the formulation and implementation of monetary policy. ${ }^{12}$

12 As such, he put forward a radical proposal to denationalize money so that free banking or currency competition would prevent governments from concealing the depreciation of the money they issue (Hayek 1978). Moreover, only the market would know the optimal quantity of money supply through a discovery process under currency competition. By contrast, in Friedman's framework (1969), the optimal quantity of money would be determined and managed by the monetary authorities in such a way that the opportunity cost of holding money balances should be reduced to zero so as to match the zero cost of creating fiat money. Friedman (1960) was initially a critic of laissez-faire banking, but he turned to become sceptical of and finally expressed more openness and sympathy towards laissez-faire banking in his later years (Friedman 1984, Friedman and Schwartz 1986). 


\section{KAM HON CHU Friedman Meets Hayek on Money and Prices}

Apparently the divergence in Friedman's and Hayek's views on money and prices cannot be completely settled once and for all by our above analysis. However, we have at least shown that in theory their different emphases on relative prices and the general price level can be reconciled to some extent so long as the central bank aims at minimizing the monetary shock. In the next section, we will turn to the empirical evidence to verify the validity of the implication of our analysis above.

\section{Empirical Evidence - The Case of Inflation Targeting in Canada}

Canada serves as a natural laboratory to empirically verify our analysis above. The year 1991 can be regarded as a watershed that an apparent regime change took place which appears to have successfully led to relatively higher monetary and price stability in subsequent years. This will be more formally confirmed with the data in the paragraphs to follow. In the spirit of Friedman (Dwyer 1999), we use the simplest possible empirical methods to examine the issue without employing tools that are more sophisticated or complicated than necessary. Another reason (or perhaps excuse) is that Hayekians or Austrians are by and large nonmathematical, if not anti-mathematical. Against this backdrop, it may be desirable to keep the econometrics or statistics from sophistication for the purpose of knowledge dissemination.

Starting in February1991, the Bank of Canada implemented inflation targeting, which can be regarded as a feedback rule in monetary policy. Under this regime, the Bank announces every five years an inflation target of $2 \%$ a year, which it has chosen to maintain at $2 \%$ since late 1995, and also conducts its monetary policy to maintain the actual inflation rate within a range of 1-3\% (see for example Laidler and Robson 2004, and more recently Melino 2012, for details). By sharp contrast, the monetary experiences during 1970-1990 are less impressive (see, e.g. Binhammer and Sephton 2001, Chapter 25 for details). In June 1970 the Bank of Canada abandoned the pegged exchange rate regime and let the Canadian dollar float. In the years 1971-74, inflation erupted partly because of the collapse of the Bretton Woods System and the first oil price hike in 1973. Against this backdrop, the Bank of Canada then chose a strategy of gradualism during 1975-82 in an attempt to target the monetary aggregate M1 so as to fight against the double-digit inflation. Although this can be viewed as some sort of monetary rule, the monetary experiment was not deemed to be successful and was abandoned largely because of the instability in money demand. Thereafter, it is not very clear what monetary rule the Bank of Canada was following in subsequent years until the late 1980s when Bank of Canada officials stated publicly that inflation had to be brought down to zero.

Based on the above short history of Canada's monetary policy since 1970, we can divide our data into two sub-samples - one running from June 1970 to January 1991, and the other 
Review of Economic Analysis 8 (2016) 69-96

from February 1991 to March 2014. ${ }^{13}$ The two subsamples are approximately the same in size. For each variable, the first subsample consists of a maximum of 248 monthly observations for each variable (depending on data availability) whereas the second subsample consists of 278 monthly observations. According to our analysis in the previous section, if the central bank chooses a monetary policy or regime that reduces monetary instability in terms of variance of the monetary shock, then, all other things equal, both the variance in the general price index and the variances in relative prices will be reduced. We examine if this is indeed the case in Canada. Hence we compute variances of the relevant variables under the inflation targeting regime and compare them with their counterparts in the previous regime.

Monthly data are obtained from the CANSIM database. To measure the variability of monetary shocks, we use different monetary supply definitions, ranging from the narrower monetary aggregates such as $\mathrm{M} 1 \mathrm{~B}, \mathrm{M} 1+$ and $\mathrm{M} 1++$ to broader monetary aggregates $\mathrm{M} 2$, M2+, M3 and M2++ (see the Data Appendix for details). For the general price level, we use the Consumer Price Index. For the relative prices, recall in Hayek's theory of the business cycle the relative price refers to not any relative price in general but more specifically the relative price between consumption goods and capital goods. From the national income account, we obtain the implicit price index for personal expenditure on consumer goods and services and also that for business fixed gross capital formation (which includes residential structures and machinery and equipment) and compute the ratio as the relative price between consumption goods and capital goods.

It may be interesting to see if our empirical findings are consistent with not only the Hayekian case in particular but also our theory in general. For the computation of relative prices in the latter general case, we try our best to avoid using the sub-aggregate price series like food, transportation, durable goods, services and so on. Instead, we use as far as possible the most dis-aggregated price series for the basket of goods and services included in the compilation of the CPI. ${ }^{14}$ These include price series for a wide range of goods and services

${ }^{13}$ There was a transition period of about four years for the Bank of Canada to bring the actual inflation rate to reach the inflation target. To allow for this, one may take the inflation targeting regime to begin in January 1996 instead. However, this does not qualitatively affect our empirical results and in fact it reinforces the main finding below that both the general price level and relative prices have become less volatile under inflation targeting.

${ }^{14}$ For analytical tractability, Hayek focused on the impact of credit-induced changes in the relative price between consumption goods and investment goods on the reallocation of resources across these two sectors rather than groups of goods in general. Hence there is a certain level of aggregation in his business cycle theory, although not as aggregative as in the Keynesian case. In our case here, the use of disaggregated data series is a test of our theory developed in Section 3: more specifically, whether the two variances given in Equations (8) and (10) tend to move, on the average, in the same direction. Our theory is more general and abstract in the sense that it applies to the relative price of any two 


\section{KAM HON CHU Friedman Meets Hayek on Money and Prices}

like apple, rice, electricity, tuition fees, eye care services, to name just a few. There are a total of 169 such price series. We arbitrarily choose the price of apple as the numeraire and deflate the other price series accordingly to come up with the series for relative prices of other goods and services. As some goods and services were introduced into the CPI basket only after February 1991, we are not able to carry a comparison of these goods and services across the two regimes. After deducting such goods and services and also the numeraire, i.e. apple (of which the relative price is always unity by definition), we have a total of 146 series of relative prices. ${ }^{15}$

The CPI series and all the monetary aggregates are non-stationary over time and show apparent upward trends. ${ }^{16}$ Therefore, we should not compare the variances based on the original data series because the variances grow over time and generate biases in the hypothesis testing. We have to de-trend each series and compute the variances of each series for each regime based on the deviations from a fitted linear time trend. ${ }^{17}$ For the various monetary aggregates, we also take their logarithmic values before we carry out detrending. On the other hand, the relative prices are taken to be all stationary. ${ }^{18}$ We can therefore

goods. It encompasses Hayek's case when the two goods of interest are consumption goods and investment goods.

${ }^{15}$ One may wonder if the choice of numeraire would affect our empirical findings and conclusion. Given a certain sample of data, the choice of numeraire will of course affect the reported findings quantitatively. That is to say, we will come up with a different set of numerical values for the variances in relative prices if, say, orange is chosen as the numeraire instead of apple. However, it can be argued that our inference and conclusion seem to be qualitatively unaffected by the choice of numeraire for at least two reasons. The first defence is a conjecture based on statistical intuition. As long as the numeraire is chosen randomly and arbitrarily, our empirical findings should be unbiased, i.e., on the average we should expect to arrive at the same statistical decision or conclusion by repeating the experiment a large number of times with a different numeraire each time. Second, and more importantly, as will be seen very shortly from the reported results below (Table 2), the variability in the relative price of consumption goods to investment goods is very clear and this finding does not rely on the choice of numeraire.

${ }^{16}$ For brevity, the unit-root test results for the CPI, the monetary aggregates and relative price series are not reported here because they are not central to our empirical analysis here. However, they are available upon request.

${ }^{17}$ This simple empirical procedure can be justified by Melino's (2011, pp. 118-9) observation that the price level in Canada under inflation targeting looks like a stationary process around trend. Of course, one may still argue that this may not be the case for the pre-inflation targeting regime or for the monetary aggregates. It is, however, well known that unit-root tests have little power to distinguish between trend stationary and drifting processes, especially in finite samples (see, e.g. Enders 1995, Chapter 4). For simplicity and consistency in comparison, therefore, we assume a stationary process around trend across the board and proceed accordingly in the empirical analysis.

${ }^{18}$ Some relative price series are stationary whereas some appear to trend upwards or downwards. Unlike the case of monetary aggregates and the CPI -- which all have an upward trend -- there does 
Review of Economic Analysis 8 (2016) 69-96

compute their variances based on the original data and then compare their changes across the two different regimes.

The variances of the monetary aggregates for the inflation targeting regime and for the previous regime are reported in the first two columns of Table 1. The penultimate column shows the numerical changes in the variances over the two regimes whereas the last column shows the percentage changes. Apparently, Canada has achieved a higher degree of monetary stability under inflation targeting as all variances have decreased considerably, both numerically and percentage-wise, after the implementation of the inflation targeting regime.

Next we turn to examine if this monetary stability due to inflation targeting has also resulted in price stability in terms of the variance of the general price level as well as the variances of the relative prices. The empirical findings are reported in Table 2. Similarly, the first two columns report the variances for the inflation targeting regime and for the previous regime, whereas the last two columns report the numerical changes and the percentage changes

Table 1: Monetary Stability under Canada's Inflation Targeting

\begin{tabular}{lcccc}
\hline $\begin{array}{l}\text { Monetary } \\
\text { Aggregates }\end{array}$ & $\begin{array}{c}\text { Previous } \\
\text { Regime, June } \\
\text { 1970- Jan.1991 }\end{array}$ & $\begin{array}{c}\text { Inflation } \\
\text { Targeting, Feb. } \\
\text { 1991-Mar 2014 }\end{array}$ & Difference & $\begin{array}{c}\text { Percentage } \\
\text { Change (\%) }\end{array}$ \\
\hline M1B & 0.0106 & 0.0012 & -0.0095 & -89.6 \\
M1+ & 0.0125 & 0.0021 & -0.0104 & -83.2 \\
M1++ & 0.0382 & 0.014 & -0.0243 & -63.6 \\
M2 & 0.0737 & 0.0279 & -0.0458 & -62.1 \\
M2+ & 0.0823 & 0.0356 & -0.0466 & -56.6 \\
M2++ & 0.0562 & 0.0241 & -0.0321 & -57.1 \\
M3 & 0.0665 & 0.0115 & -0.055 & -82.7 \\
\hline
\end{tabular}

Note: The reported figures in the first two columns are variances of the deviations from trends. See the text for more details.

not appear to be any systematic patterns in the trends of these relative prices. Moreover, for each series, the range of fluctuations is so narrow that the trend slope tends to be small in magnitude. As a result, the potential bias in the variance is expected to be small as well. For simplicity, therefore, we take these series as stationary and proceed with the subsequent empirical analysis. 
KAM HON CHU Friedman Meets Hayek on Money and Prices

Table 2: Price Stability under Canada's Inflation Targeting

\begin{tabular}{lcccc}
\hline & $\begin{array}{c}\text { Previous } \\
\text { Regime, June } \\
\text { 1970- Jan.1991 }\end{array}$ & $\begin{array}{c}\text { Inflation } \\
\text { Targeting, Feb. } \\
\text { 1991-Mar 2014 }\end{array}$ & Difference & $\begin{array}{c}\text { Percentage } \\
\text { Change (\%) }\end{array}$ \\
\hline CPI & 21.8776 & 15.3078 & -6.5698 & -30 \\
$\begin{array}{l}\text { Consumption Goods } \\
\text { Investment Goods }\end{array}$ & $3.846 \times 10^{-3}$ & $0.533 \times 10^{-3}$ & $-3.31 \times 10^{-3}$ & -86.1 \\
\hline
\end{tabular}

Note: The reported figures in the first two columns are variances. For the CPI, they are variances of the deviations from trends. See the text for more details.

variances over the two regimes. As can be seen, the first row of results indicate clearly that Canada has achieved a higher degree of price stability under inflation targeting as measured by the variability of the CPI.

For relative-price stability, we first consider the stability of the relative price between consumption goods and investment goods as measured by the ratio of the implicit price index for personal expenditure on consumer goods and services to that for business fixed gross capital formation. This relative price fluctuated within a narrow range between 0.7 and 1.02, with a mean of 0.79 under the pre-inflation targeting regime and 0.89 under inflation targeting. This seems to lend some support to Hayek's theory that monetary injections induce forced savings and hence producers' good prices will rise relatively more than consumption prices, although further empirical investigation to verify Hayek's theory is necessary. Nevertheless, this relative price between consumption goods and capital goods also supports our theory as its variance has registered a dramatic percentage decrease to become significantly smaller under inflation targeting (see the last row in Table 2).

For relative-price stability measured by the relative prices of the goods in the CPI basket, the results are reported in Table 3. For brevity, we do not report all the variances for the 146 relative prices here. ${ }^{19}$ Instead we report only the averages and also some selected extreme values so that the reader can have a general idea about the magnitudes and changes in those variances. More specifically, oral hygiene products had the largest variance for the period before inflation targeting, whereas jewellery posted the smallest variance. For the inflation targeting regime, video equipment had the largest variance while fresh or frozen beef had the smallest variance. Across the regimes, oral hygiene products registered the largest decline in the variance, whereas sugar and syrup recorded the smallest decline. On the other hand, photographic equipment and supplies posted the largest increase in variance while eye care

\footnotetext{
${ }^{19}$ The complete empirical results are available upon request.
} 
Review of Economic Analysis 8 (2016) 69-96

goods experienced the smallest increase. In sharp contrast to the CPI and monetary aggregates which have become less volatile after the introduction of inflation targeting, these last findings indicate that not all variances of relative prices have become smaller over time. This phenomenon is, of course, possible in both theory and practice because changes in relative prices reflect not only monetary shocks but also real shocks, say, shifts in consumption patterns over time.

Out of the 146 relative prices, 37 (or roughly 1/4) have increases in their variances under the inflation targeting regime. The average variance for all goods and services has declined by 0.046 over the two regimes. ${ }^{20}$ More formally, we can applied Wilcoxon's signed- rank test for matched pairs to obtain more definite evidence that variances have on average fallen under the inflation targeting regime. We can, therefore, carry out a one-sided test based on the following null and alternative hypotheses respectively:

Table 3: Relative-Price Stability of Selected Goods under Canada's Inflation Targeting

\begin{tabular}{lcccc}
\hline & $\begin{array}{c}\text { Previous } \\
\text { Regime, June } \\
\text { 1970- Jan.1991 }\end{array}$ & $\begin{array}{c}\text { Inflation } \\
\text { Targeting, Feb. } \\
\text { 1991-Mar 2014 }\end{array}$ & Difference & $\begin{array}{c}\text { Percentage } \\
\text { Change (\%) }\end{array}$ \\
\hline Average & 0.0774 & 0.0314 & -0.046 & -59.4 \\
$\begin{array}{l}\text { Oral hygiene } \\
\text { products }\end{array}$ & 1.5629 & 0.0648 & -1.4981 & -95.9 \\
Jewellery & 0.0071 & 0.0129 & 0.0058 & 81.7 \\
Video Equipment & 0.1933 & 0.3685 & 0.1752 & 90.6 \\
Fresh/Frozen Beef & 0.0749 & 0.0057 & -0.0693 & -92.5 \\
$\begin{array}{l}\text { Photo Equipment \& } \\
\text { Supplies }\end{array}$ & 0.0533 & 0.2807 & 0.2274 & 426.6 \\
Eye Care Goods & 0.0243 & 0.0247 & 0.0004 & 1.6 \\
Sugar \& Syrup & 0.0206 & 0.0204 & -0.0003 & -1.5 \\
\hline
\end{tabular}

Note: The reported figures in the first two columns are variances.

${ }^{20}$ If January 1996 is taken as the beginning of the inflation targeting regime, then only 28 relative prices (or roughly 1/5) have increases in their variances under the inflation targeting regime, and the average variance of all goods and services has declined by 0.0053 over the two regimes. 


\section{KAM HON CHU Friedman Meets Hayek on Money and Prices}

$\mathrm{H}_{0}$ : There is no difference in the variances of the relative prices on average before and after the implementation of inflation targeting.

$\mathrm{H}_{1}$ : On average the variances of relative prices are higher before the implementation of inflation targeting.

Accordingly, we take the differences between the matched pairs of variances and their ranks to compute the rank sum (the test statistic); and we reject the null hypothesis if the test statistic is smaller than the critical value (see Wilcoxon 1945 or Neave and Worthington 1988 for details). In a large sample like ours, the null distribution of the test statistic can be approximated by a normal distribution. The rank sum is 2,113 , which is smaller than both the $5 \%$ critical value of 4,523 and $1 \%$ critical value of 4,172 . In other words, there is strong evidence of a reduction in variances of the relative prices after implementation of inflation targeting. ${ }^{21}$

Although only rudimentary statistical methods are employed, our findings are consistent with much of the existing empirical literature that points to a positive relationship between inflation and relative price variability for many countries and for various time periods. Interestingly, as far as inflation targeting is concerned, a recent empirical study by Choi, Kim and O'Sullivan (2011), whose summary statistics show that while inflation targeting has brought down the mean inflation rate in Canada, the average relative price variability has slightly increased. The discrepancy between their findings and those of this study can be attributed partly to the difference in sampling periods and perhaps largely to the difference in the definitions, and hence measurements, in relative price variability. ${ }^{22}$ Indeed, the term relative price variability used in that empirical literature should more appropriately and accurately be called relative inflation variability. ${ }^{23}$

\section{Conclusions}

One aspect in which Friedman and Hayek differed in monetary economics lies in the microfoundations of macroeconomics. In the Monetarist Counter-Revolution to the Keynesian Revolution, Friedman adopted the quantity theory of money as his theoretical framework and used the general price indexes and aggregate data in his empirical analysis. The analytical framework and methods are in line with Keynesian macroeconomics that has dominated the economic profession after World War II. By contrast, Hayek rejected such

${ }^{21}$ Again if January 1996 is taken as the beginning of the inflation targeting regime, the rank sum is 1,385 and the conclusion remains intact.

22 Their sample period is from January 1984 to February 2009, and they choose only eight subaggregate items from the consumer price index.

${ }^{23}$ In that literature, relative price variability is commonly defined as RPV $=\sum w_{\mathrm{it}}\left(\pi_{\mathrm{it}}-\pi_{\mathrm{t}}\right)^{2}$, where $\pi_{\mathrm{it}}$ is inflation in the individual commodity $i$ and $\pi_{\mathrm{t}}$ is the inflation rate. 
aggregative analyses for they can be misleading and meaningless. Instead, he focused on the impact of money on relative prices in his business cycle theory - how money injections can distort relative prices and hence lead to misallocation of resources. His rejection of modern macroeconomics follows from the methodological individualism of the Austrian School.

This paper has demonstrated that the gap between these two great economists in their methods of analysis can be to some extent narrowed as far as the emphases on relative prices and the general price level are concerned. Based on the definition of consumer price index and also a very simple assumption that the price of a good is subject to real and monetary shocks, this study shows theoretically that variances in the general price index and in relative prices are not equivalent in general. However, when the central bank chooses a monetary policy to minimize the monetary shock so as to maintain stability in the general price level, it also maintains simultaneously relative price stability. Contrary to what Hayek claimed, the general price level is not irrelevant in this perspective, and also it is in practice an operationally more feasible target and indicator when compared with relative prices that are so numerous and costly for the central bank to monitor in reality.

This theoretical finding is empirically verified by Canada's experience with inflation targeting since 1991. The empirical results show that both the general price level and relative prices have become less volatile during the inflation targeting regime when compared with the previous regime from June 1970 to January 1991. Although Friedman and Hayek had different theories on the transmission mechanism through which money affects aggregate activity and they also put different emphases on the general price level and relative prices, they did see eye to eye with each other in that an appropriate, if not ideal, monetary policy should be one that does not induce disturbances and distortions to the price mechanism. Moreover, both of them would probably agree to give the Bank of Canada a good grade in the report card whether the evaluation is based on the general price level stability or relative-price stability.

All in all, although both Friedman and Hayek are advocates of free market economics, their economic views are by no means identical, particularly in the area of monetary economics. Given their diverse backgrounds in terms of intellectual heritage, methodology, and philosophy, it is not surprising that it is highly unlikely, if possible at all, to have a reconciliation in their differences in monetary theory and policy. This is by no means the aim of this paper. It is certainly more important and fruitful to have a better understanding of their views than to have a reconciliation. Indeed, it is the fortune of humanity to have these two great thinkers - rather than only one if their views were identical - to enrich our knowledge and thoughts! 


\section{KAM HON CHU Friedman Meets Hayek on Money and Prices}

\section{Mathematical Appendix}

This appendix shows the derivations of the variance of the general price level as well as that of relative prices. First, consider the general price level index. Following the notation and assumptions given in the text, the covariance between $P_{i t}$ and $P_{j t}$, is:

$$
\operatorname{COV}\left(P_{i t}, P_{j t}\right)=E\left[\left(P_{i t}-E\left(P_{i t}\right)\right)\left(P_{j t}-E\left(P_{j t}\right)\right]\right.
$$

Expanding the terms inside the brackets yields:

$$
\operatorname{COV}\left(P_{i t}, P_{j t}\right)=E\left[P_{i t} P_{j t}-P_{i t} E\left(P_{j t}\right)-P_{j t} E\left(P_{i t}\right)+E\left(P_{i t}\right) E\left(P_{j t}\right)\right]
$$

As it is assumed that the real shocks are uncorrelated with the monetary shock, we can consider the real part and the monetary part separately. The covariance of the real shocks is simply given as $\sigma_{i j}$. The covariance due to the monetary shock is

$$
E\left[\left(a_{i} m_{t}-E\left(a_{i} m_{t}\right)\right)\left(a_{j} m_{t}-E\left(a_{j} m_{t}\right)\right)\right]
$$

After expanding the above expression and collecting terms yield

$$
a_{i} a_{j} E\left[m_{t}^{2}-E\left(m_{t}\right)^{2}\right]
$$

But $\mathrm{E}\left[m_{t}^{2}-\mathrm{E}\left(m_{t}\right)^{2}\right]=\sigma_{m}{ }^{2}$. So adding up the real part and the monetary part gives

$$
\operatorname{COV}\left(P_{i t}, P_{j t}\right)=\sigma_{i j}+a_{i} a_{j} \sigma_{m}^{2}
$$

which is Equation (6) in the text. Then Equation (8) follows from taking the variance of Equation (2) and substituting Equations (5) and (6) into it.

Next consider the variance of the relative price $P_{i t} / P_{j t}$. The variance of the quotient of two random variables can be approximated by a formula given in Mood, Graybill and Boes (1974, Equation (15) on p. 181):

$$
\operatorname{var}\left[\frac{X}{Y}\right] \approx\left(\frac{\mu_{x}}{\mu_{y}}\right)^{2}\left(\frac{\operatorname{var}[X]}{\mu_{x}^{2}}+\frac{\operatorname{var}[Y]}{\mu_{y}^{2}}-\frac{2 \operatorname{cov}[X, Y]}{\mu_{x} \mu_{y}}\right)
$$

where $\mu_{x}$ and $\mu_{y}$ are respectively the means of two random variables $X$ and $Y$. Now the two random variables in our case here are $P_{i t}$ and $P_{j t}$. Their means, variances and covariance are 
Review of Economic Analysis 8 (2016) 69-96

given by Equations (4), (5) and (6) respectively. Substituting these equations into the above formula (A6) to get

$$
V\left(\frac{P_{i t}}{P_{j t}}\right)=\left(\frac{\mu_{i}}{\mu_{j}}\right)^{2}\left[\frac{a_{i}^{2} \sigma_{m}^{2}+\sigma_{q i}^{2}}{\mu_{i}^{2}}+\frac{a_{j}^{2} \sigma_{m}^{2}+\sigma_{q j}^{2}}{\mu_{j}^{2}}-\frac{2\left(a_{i} i a_{j} \sigma_{m}^{2}+\sigma_{i j}\right)}{\mu_{i} \mu_{j}}\right]
$$

By expanding and collecting the terms inside the brackets, it is straightforward to get

$$
V\left(\frac{P_{i t}}{P_{j t}}\right)=\left(\frac{\mu_{i}}{\mu_{j}}\right)^{2}\left[\left(\frac{\sigma_{q i}^{2}}{\mu_{i}^{2}}+\frac{\sigma_{q j}^{2}}{\mu_{j}^{2}}-\frac{2 \sigma_{i j}}{\mu_{i} \mu_{j}}\right)+\left(\frac{a_{i}^{2}}{\mu_{i}^{2}}+\frac{a_{j}^{2}}{\mu_{j}^{2}}-\frac{2 a_{i} a_{j}}{\mu_{i} \mu_{j}}\right) \sigma_{m}^{2}\right]
$$

which is Equation (10) in the text.

\section{Data Appendix}

All data used in the empirical analysis in this study are downloaded from the CANSIM database at http://dc1.chass.utoronto.ca/cansimdim. The series names and the corresponding CANSIM series numbers are listed below:

$\begin{array}{ll}\text { M1B } & \mathrm{v} 41552795 \\ \text { M1+ } & \mathrm{v} 37151 \\ \text { M1++ } & \mathrm{v} 37152 \\ \text { M2 } & \mathrm{v} 41552796 \\ \text { M2+ } & \mathrm{v} 41552798 \\ \text { M2++ } & \mathrm{v} 41552801 \\ \text { M2 } & \mathrm{v} 41552794 \\ \text { Consumer Price Index } & \mathrm{v} 41690973 \\ \begin{array}{l}\text { Implicit price index for personal expenditure } \\ \text { on consumer goods and services }\end{array} & \mathrm{v} 1997738 \\ \begin{array}{l}\text { Implicit price index for business } \\ \text { gross capital formation }\end{array} & \mathrm{v} 1997745\end{array}$

For brevity, not listed above are another 147 price series of product and product groups selected from the Consumer Price Index basket of goods and services. They are from the CANSIM Table 3260020. A complete list of these selected price series and their series numbers are available upon request. 


\section{KAM HON CHU Friedman Meets Hayek on Money and Prices}

\section{References}

Ambler, S. (2009) Price-Level Targeting and Stabilization Policy: A Survey. Journal of Economic Surveys 23(5), 974-97.

Bellante, Don, and Roger Garrison (1988) Phillips Curves and Hayekian Triangles: Two Perspectives on Monetary Dynamics. History of Political Economy 20(2), 207-34.

Binhammer, H.H. and P. Sephton (2001) Money, Banking, and the Canadian Financial System, $8^{\text {th }}$ edition. Scarborough: Nelson Thomson Learning.

Blanchard, O., and J. Gali (2007) Real Wage Rigidity and the New Keynesian Model. Journal of Money, Credit and Banking 39(1), 35-65.

Bordo, Michael, and Hugh Rockoff (2013) The Influence of Irving Fisher on Milton Friedman's Monetary Economics. Journal of the History of Economic Thought 35(2), 15377.

Brunner, Karl (1968) The Role of Money and Monetary Policy. Federal Reserve Bank of St. Louis Review 50, July,1968, 8-24.

Choi, Chi-Young (2010) Reconsidering the Relationship between Inflation and Relative Price Variability. Journal of Money, Credit and Banking 42(5), 769-98.

Choi, Chi-Young, Young Se Kim and Roisin O’Sullivan (2011) Inflation Targeting and Relative Price Variability: What Difference Does Inflation Targeting Make? Southern Economic Journal 77(4), 934-57.

Colona, M., and H. Hagemann (eds.) (1994) Money and Business Cycles: The Economics of F.A. Hayek Volume I. Edward Elgar.

Dwyer, Gerald P., Jr. (1999) How was Milton Friedman Distinctive as a Teacher? in Daniel Hammond (ed.) The Legacy of Milton Friedman as Teacher, Edward Elgar.

Enders, Walter (1995) Applied Econometric Time Series. New York: John Wiley \& Sons.

Fisher, Irving (1922) The Purchasing Power of Money, second edition, New York: Macmillan.

Friedman, Milton (1956) The Quantity Theory of Money - A Restatement, in M. Friedman (ed.) Studies in the Quantity Theory of Money, University of Chicago Press. . (1959) The Demand for Money: Some Theoretical and Empirical Results. Journal of Political Economy 67, 327-51. . (1960) A Program for Monetary Stability. New York: Fordham University Press. . (1961) The Lag in the Effect of Monetary Policy, reprinted in M. Friedman. Optimal Quantity of Money and Other Essays. Chicago: Aldine. . (1964) Monetary Studies of the National Bureau, pp. 7-25 in The National Bureau

Enters its $45^{\text {th }}$ Year, 44 ${ }^{\text {th }}$ Annual Report, 1964, reprinted as pp. 261-84 in M. Friedman Optimal Quantity of Money and Other Essays. Chicago: Aldine. . (1968) The Role of Monetary Policy. American Economic Review 58(1), 1-17. 
Review of Economic Analysis 8 (2016) 69-96

. (1969) Optimal Quantity of Money and Other Essays. Chicago: Aldine.

(1970) A Theoretical Framework for Monetary Analysis. Journal of Political

Economy 78, 193-238.

. (1971) A Monetary Theory of Nominal Income. Journal of Political Economy 79, 323-7.

. (1984) Currency Competition: A Sceptical View. in P. Salin (ed.) Currency Competition and Monetary Union. The Hague: Martinus and Nijhoff.

. (1988) The Case for Flexible Exchange Rates, pp. 3-42 in L. Melamed (ed.) The Merits of Flexible Exchange Rates. George Mason University Press.

. (1993) The "Plucking Model" of the Business Cycle Fluctuations Revisited. Economic Inquiry 31, 171-7.

Friedman, Milton, and Rose D. Friedman (1998) Two Lucky People, University of Chicago Press.

Friedman, Milton, and David Meiselman (1963) The Relative Stability of Monetary Velocity and the Investment Multiplier in the United States, 1897-1958, in Stabilization Policies, Englewood Cliffs, N.J.: Prentice-Hall, pp. 165-268.

Friedman, Milton, and Anna Schwartz (1963) A Monetary History of the United States, 18671960. Princeton University Press.

. (1986) Has Government Any Role in Money? Journal of Monetary Economics $17,37-62$.

Garrison, Roger (1996) Friedman's 'Plucking Model': Comments. Economic Inquiry 34, 799802.

(2013) Hayek and Friedman: Head to Head, in Roger Garrison and Norman Barry (eds.) The Elgar Companion to Hayekian Economics, Cheltenham: Edward Elgar.

Hammond, J.D. (1992) An Interview with Milton Friedman on Methodology. The History of Economic Thought and Methodology 10, 91-118.

Hayek, F.A. von (1925) The Monetary Policy of the United States after the Recovery from the 1920 Crisis, in Stephen Kresge (ed.) (1984) Good Money Part I: The New World, The University of Chicago Press, pp. 71-151.

. (1931) Reflections on the Pure Theory of Money of Mr. J.M. Keynes Part I. Economica 11, 270-95.

. (1932) Reflections on the Pure Theory of Money of Mr. J.M. Keynes Part II.

Economica 11, 398-403.

. (1933) On 'Neutral' Money'. First published as "Über 'neutrale Geld"” in

Zeitschrift für Nationalökonomie vol. 4, 1933, pp. 659-661. Translated and reprinted in

Good Money Part I: The New World, S. Kresge (ed.) (1984) Chicago: University of Chicago Press, pp. 228-31.

. (1935) Prices and Production, $2^{\text {nd }}$ edition, London: Routledge. 


\section{KAM HON CHU Friedman Meets Hayek on Money and Prices}

. (1939) Monetary Nationalism and International Stability. Geneve: IHS. Reprinted as Chapter 1 in Good Money Part II: The Standard, S. Kresge (ed.) (1984) Chicago: University of Chicago Press, pp. 1-100. . (1942) The Ricardo Effect. Economica 34, 127-52. . (1943) A Commodity Reserve Currency. Economic Journal 53, 176-84.

. (1967) Three Elucidations of the Ricardo Effect. Journal of Political Economy $77(2), 274-85$.

. (1978) Denationalization of Money, $2^{\text {nd }}$ ed. Hobart Special Paper 70, London: Institute of Economic Affairs.

. (1994) Hayek on Hayek: An Autobiographical Dialogue. S. Kresge and L. Wenar (eds.) Chicago: University of Chicago Press.

Hicks, J.R. (1967) Monetary Theory and History - An Attempt at Perspective, as Chapter 9, pp. 155-73 in J.R. Hicks (1967) Critical Essays in Monetary Theory. Oxford: Clarendon Press.

. (1973) Capital and Time: A Neo-Austrian Theory. Oxford: Clarendon Press.

Kamenik, O., H. Kiem, V. Klyuev, and D. Laxton (2013) Why is Canada's Price Level so Predictable? Journal of Money, Credit and Banking 45(1), 71-85.

Keynes, J.M. (1930) A Treatise on Money. London: Macmillan.

Laidler, David (1991) The Golden Age of the Quantity Theory. Princeton University Press. . (2003) The Price Level, Relative Prices, and Economic Stability: Aspects of the Inter-war Debate. BIS Working Papers No. 136. Basel: Bank for International Settlements.

Laidler, David, and William Robson (2004) Two Percent Target: Canadian Monetary Policy since 1991, Toronto: C.D. Howe Institute.

Lucas, Robert E. Jr. (1972) Expectations and the Neutrality of Money. Journal of Economic Theory 4, 103-24.

. (1973) Some International Evidence on Output-Inflation Tradeoffs. American Economic Review 63, 326-34.

Melino, Angelo (2012) Inflation Targeting: A Canadian Perspective. International Journal of Central Banking 8(S1), 105-31.

Mood, A.M., F.A. Graybill and D.C. Boes (1974) Introduction to the Theory of Statistics, 3rh edition. New York: McGraw-Hill.

Murchison, S. (2010) Price-Level Targeting and Relative-Price Shocks. Bank of Canada Review, Summer 2010, 11-21.

Neave, H.R., and P.L. Worthington (1988) Distribution-Free Tests. London: Unwin Hyman.

Parks, Richard (1976) Inflation and Relative Price Variability. Journal of Political Economy 86(1), 79-95.

Robertson, D.H. (1926) Banking Policy and the Price Level. London: Macmillan. 
Review of Economic Analysis 8 (2016) 69-96

Simons, H. (1936) Rule versus Authorities in Monetary Policy. Journal of Political Economy 44, 1-30.

Skousen, Mark (2005) Vienna \& Chicago: Friends or Foes, Washington, D.C.: Capital Press.

Vining, Daniel, and Thomas Elwertowski (1976) The Relationship between Relative Prices and the General Price Level. American Economic Review 66(4), 699-708.

Wilcoxon, F. (1945) Individual Comparisons by Ranking Methods. Biometrica 1, 80-3. 